\title{
Strategies of Plant Biotechnology to Meet the Increasing Demand of Food and Nutrition in India
}

\author{
Santanu De \\ Department of Biological Sciences, Halmos College of Arts and Sciences, Nova Southeastern University, \\ 3301 College Avenue, Fort Lauderdale, Florida 33314, U.S.A.
}

Corresponding author email: sde@nova.edu

Received: 05 June 2020 / Revised: 31 July 2020 / Accepted: 20 August 2020 / Published: 04 September 2020

\begin{abstract}
A groundbreaking application of biotechnology research during the recent past has been improvement of crop health and production. India being one of the most rapidly developing countries with an enormous population and remarkable biodiversity, plant biotechnology promises significant potential to contribute to characterization and conservation of the biodiversity, increasing its usefulness. However, India's green revolution was noted to be insufficient to feed the country's teeming millions. Therefore, novel approaches in crop biotechnology had to be aimed at ensuring better productivity and quality of cultivars. This paper provides a comprehensive review of research undertaken mainly in the last couple of decades along with potential strategies in plant biotechnology focusing on specific grain and seed crops of key agricultural as well as dietary importance to meet the growing demand of food and nutrition in India, while also proposing potential application of relevant global research findings in the Indian context. The analysis would help address the ever-increasing worldwide socioeconomic necessity for greater food security, particularly during times of crisis such as the recent Coronavirus Infectious Disease 2019 (COVID-19) pandemic.
\end{abstract}

Keywords: Plant biotechnology, crop production and yield, disease resistance, food and nutritional demands, India.

\section{Introduction}

Several developing, agro-based countries like India focus their biotechnology research on food crops and cultivars of high commercial value to meet increasing food requirements and reducing poverty, particularly among resourcepoor farming households. Among multifaceted benefits of plant biotechnology are drought and salt tolerance, and biofortification that enhances micronutrient content, while the relevant modern techniques involve agricultural genome editing, RNA spraying technology and consideration of future targets to strengthen environmental and food security [1]. Indian agriculture currently entails the search, characterization, isolation, and utilization of new genes across taxa for imparting desirable traits in crops through the application of biotechnology. Catering to an essential prerequisite, India's remarkable biodiversity provides a fertile ground for research on crop plant genes.

India's Green Revolution initiated substantial improvements in food security, poverty reduction and per capita income. The per capita gross domestic product increased between 1970 and 1995 by 190\%, cereal production doubled, and calorie availability per person increased by $24 \%$ [2]. In the Green Revolution, crop yields surged with the use of new varieties of food plants and modern farming methods. India's National Agricultural Research System (NARS) has been responding to evolving concerns and is poised to continue doing so in the years ahead.

However, as a major challenge, the achievements of the green revolution were proving insufficient for feeding India's huge human population of 1.339 billion (2017 data) and counting. A plateau was observed in India's 
agricultural yield and pre-existing technologies may not have any longer been enough to meet the pressing food demand; additionally, numerous Indian children, especially aged 1 to 4 years, were found undernourished [3]. Apart from that, globalization and urbanization of late have exposed Indian masses to easier access to calorierich, sugary and fat food items as regular inclusion of cereals in daily diet has been declining across developing nations, concomitant with a rise in consumption of processed or purchased food and animal-based proteins [4]. These can lead to a lot of nutritional deficiencies and adverse health consequences.

Biotechnology could help solve several of the problems that limit production of crop, livestock, and fisheries in developing countries. Biotechnological interventions can play a vital role by increasing crop productivity as well as countering the increasing threat of biotic and abiotic stresses to crop plants. Genetically modified (GM) crops are so useful to farmers because they can be engineered to have increased nutritional value and be resistant to diseases and pests. Better understanding of plant physiology, genomics, proteomics, phytochemistry, biosynthetic pathways, molecular biology and metabolic regulation have catapulted the quantity and quality of food supply in India through biotechnologically triggered efficiency of photosynthesis, resilience against extreme environments such as frost, drought, salinity and alkalinity, ability to combat plant pathogens or insect pests, and greater responsiveness to agrochemicals to increase crop yields. Application of biotechnology in crop improvement programmes has started giving dividends, with entirely indigenous efforts. About 50 public research units in India have been constructed to use tools of modern biotechnology for agriculture.

This paper aims at reviewing and suggesting key plant biotechnological strategies undertaken mainly in the past couple of decades or those that could potentially be considered by scientists in near future to meet the increasing demand of food and nutrition for humans and domestic animals in India.

\section{Crop-specific biotechnological approaches}

A number of multi-institutional projects have been launched in India, bringing forth transgenics for resistance to Gemini-viruses in cotton, mung-bean, and tomato, to 'tungro' disease in rice, to bollworms in cotton, to develop a nutritionally uplifted potato with a balanced amino acid composition, and to regulate the molecular mechanisms for heterosis breeding. The first GM crop to be released for commercial cultivation in India was Bt cotton, 'Bt' referring to the soil bacterium Bacillus thuringiensis from which the cry1Ac gene was incorporated into cotton, rendering it toxic to bollworms, though further cost-effective varieties have been produced [5]. Considerable research progress has been made with cardamom and vanilla, both prevalent crops. Other transgenic crops that have awaited approval for commercial cultivation include transgenic herbicide-tolerant mustard hybrids and nutritionally enhanced potato varieties. Notable biotechnological measures undertaken or likely useful for pertinent Indian food plants of agricultural and dietary significance are reviewed below.

\subsection{Rice}

India's Green Revolution owes much to the introduction of genetically improved varieties of rice and wheat. Dwarfing genes were successfully transferred from the well-known Japanese Norin-10 wheat and Chinese Dee-geowoo-gen (DGWG) rice cultivars. The new varieties increased food-grain production manifold. Biochemical and molecular assays can be effectively employed to identify alternate sources of dwarfing gene compared to the Green Revolution rice gene $s d 1$ [6]. Two rice species, Oryza sativa and Oryza glaberrima have been predominantly cultivated but their wild and uncultivated species are the source of genes for better rice varietie. For resistance against grassy stunt virus, the gene (Gsv 1) was transferred in rice from Oryza nivara; likewise, the source for the genes to develop resistance to brown plant hopper and white-backed plant hopper was Oryza officinalis. Other important genes introgressed from wild species of rice into the cultivated 
Santanu De, Int. Ann. Sci.; Vol. 10, Issue 1, pp: 7-15, 2021

species include genes for tolerance to drought from Oryza glaberrima, resistance to rice 'tungro' virus from Oryza latifolia, resistance to drought coming from Oryza rufipogon, and resistance to Yellow stem borer (YSB) being introgressed from Oryza ridleyi [7].

An International Rice Research Institute (IRRI) project promising immense benefit to human nutrition has been golden rice, genetically engineered to over-express beta-carotene - the precursor to vitamin $A$ as an inexpensive way to deliver the vitamin to millions of poor people in their staple food, rice. Golden rice was designed to produce beta-carotene in the edible part of rice, the endosperm [8]. The rice plant can naturally generate beta-carotene, which is a carotenoid pigment in the leaves involved in photosynthesis. However, since photosynthesis does not take place in the endosperm, the plant does not normally produce the pigment in the endosperm. Golden rice was created by transforming rice (by an endosperm-specific promoter), with three beta-carotene biosynthesis genes: psy (phytoene synthase) and lyc (lycopene cyclase) - both from daffodil (Narcissus pseudonarcissus), and crt1 from the soil bacterium Erwinia uredovora. This engineered pathway leads to formation of the end product, lycopene. The plant's endogenous enzymes convert the lycopene to beta-carotene in endosperm as depicted in figure 1 [9], giving the rice the yellow color for which it is named.

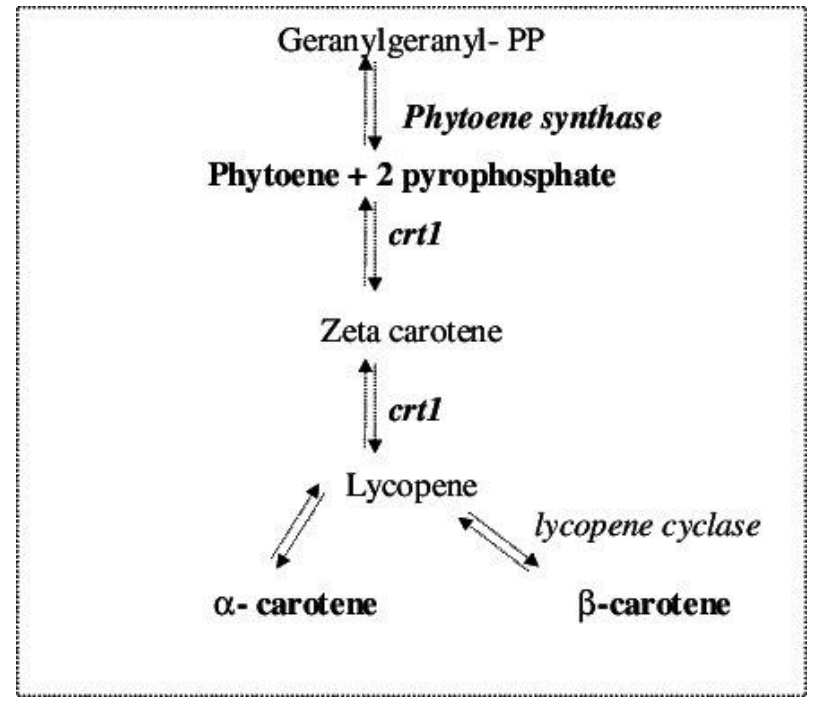

Figure 1: Schematic representation of the carotenoid biosynthesis pathway showing the enzymes expressed in the endosperm of golden rice [9].
The original golden rice was called SGR1. In 2005, a new variety called golden rice 2 (GR2) was created with more intense yellow rice grains due to considerably greater amounts of beta-carotene than in SGR1, shown in figure 2 [10]. The golden rice benefitted children and pregnant women suffering from vitamin A deficiency.

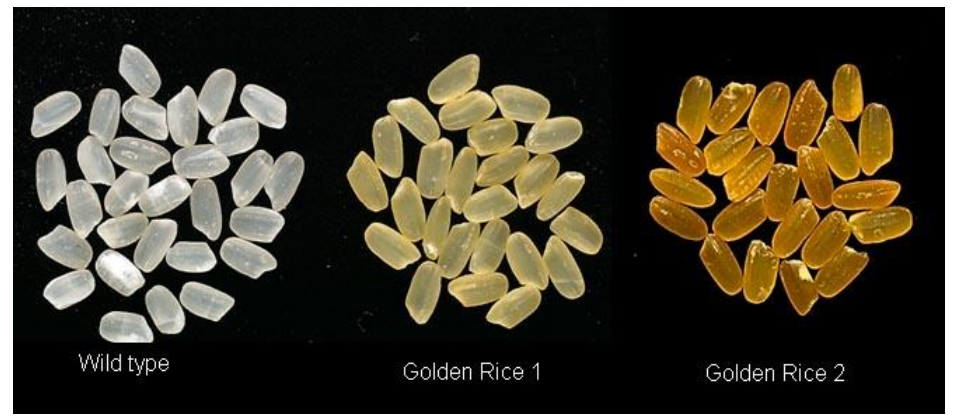

Figure 2: Grains of original golden rice (SGR1) and golden rice 2 (GR2) compared to wild type rice. GR2 contains beta-carotene levels that will provide adequate quantities of provitamin A as part of children's diet in southeast Asia [10].

Along with the golden rice, attempts have been made to produce a new rice variety with a bacterial gene for combating stem borer, or with additional rice genes for resistance to bacterial blight and sheath blight, as well as with genes from other plant species and bacteria with the purpose of creating an iron-rich rice and improving grain filling. Another variety is known as "aerobic rice", requiring lesser water to survive [11]. Broad-spectrum resistance to bacterial blight in rice has been developed recently through genome editing, and paddy trials indicated that genome-edited SWEET promoters produce rice lines with such robust resistance [12]. A relevant project has identified and cloned genes encoding putative rice serine protease inhibitors ('serpins'), a conserved superfamily of proteins that inhibit serine protease targets and prevent plant programmed cell death (PCD) in absence of pathogen infection [13]. Biotic stress of rice and its control by biotechnological and molecular aspects have been documented with the goal of decreasing the use of insecticides and fungicides to eventually ascertain the safety of rice as food as well as of the environment. 


\subsection{Wheat}

Wheat is the most common staple cereal after rice in India and probably was the earliest cultivated. The rust disease has caused tremendous damage to wheat crop. Agricultural scientists are engaged the world over in bringing betterment of wheat varieties through transfer of genes that impart rust resistance. Leaf rust (Puccinia triticina) is one of the major biotic stress factors that affect the yields of wheat. Transgression of the genes for resistance to black rust and brown rust in wheat have come from Aegilops speltoids and Aegilops elongatum. Research aspiring to attain varieties of wheat showing higher yield potential, improved nutritional quality, biotic and abiotic resistance have resulted in overall enhancement of wheat germplasm. The development of tetraploid and hexaploid wheat are well known examples of hybridization influencing the nutritional quality [14]. New sources of resistance to wheat stem rust in Aegilops spp. have been identified in the tertiary gene-pool of wheat [15]. Another recent study has detected novel genetic sources of disease resistance that can be successfully applied in breeding of wheat [16]. In addition to high yield, abiotic stress factors including drought tolerance and temperature, and biotic stress tolerance traits like pathogen and insect pest resistance needs clarification of how to fight the adverse influences of climate change on wheat productivity. Hence, generation of diseaseresistant, high-yielding varieties with stronger nutritional value should be the overarching purpose of wheat breeding [17]. Segregating population of dwarfing genes $(R h t), R b t 1$ and $R h t 8$ generated by European winter wheats and spring wheat varieties have highlighted the potential of alternate dwarfing gene in the Indian subcontinent, as candidate for conservation agriculture - an emerging breeding objective in response to climate change [18]. Current and future concerns and challenges to wheat agriculture in India involve sustenance of production and quality with decreased input of agrochemicals, and propagating lines with heightened quality for human nutrition and biofuels [19].

\subsection{Potato}

The nutritive value of various crop plants has been successfully improved as a major long-term goal of plant breeding programs. Potato is one of the most important non-cereal food crops. In order to add to the nutritional quotient of potato, the coding sequence of the cloned gene for AmA1 seed albumin protein from Amaranthus hypochondriacus was successfully introduced and expressed in tuber-specific and constitutive manner by using granule-bound starch synthase (GBSS) and cauliflower mosaic virus (CaMV) 355 promoters, respectively [20]. It increased the growth and production of tubers in transgenic populations particularly rich in the essential amino acids lysine and tyrosine as well as sulfur amino acids with rise in total protein content [21]. The expressed protein was localized in cytoplasm and vacuoles of the transgenic tubers. Thus, to develop a transgenic crop plant, a seed albumin gene product with a well-balanced amino acid composition has been used as a donor protein. Proteome rebalancing in transgenic tuber resulted in expression of the seed protein gene AmA1 in next-generation, protein-rich potato [22]. In quality improvement programs of potato, the priorities have been to strengthen disease- and pest-resistance, to propel yields, and to increase adaptability to biotic and abiotic conditions - for instance, a synthetic antifreeze protein gene expressed in plants decreased leakage of electrolytes from leaves at freezing temperatures [23]. Marked advances have been made in genetic transformation of potato to enrich in its nutritional and therapeutic values by augmenting functional secondary metabolites, carbohydrates, essential amino acids, proteins, lipids, vitamins and edible vaccines [24].

\subsection{Tomato}

Recent progress and challenges associated with tomato mutagenesis research have reviewed that tomato yield and quality could be uplifted by judicious combination of existing well-characterized tomato mutant resources with cutting-edge mapping approaches to accelerate mutation breeding; for example, Mutmap, MutChromeSeq and whole-genome sequencingbased mapping [25]. The WRKY1 transcription 
factor augments resistance to early blight (EB) in wild tomato, which could be tapped as a putative target via genetic engineering to induce defense against Alternaria solani that causes EB in crop plants [26]. Tomato transformation with Cry2ax1 was conducted by Bolistic Gun Method for imparting resistance to the fruit borer insect, Helicoverpa armigera Hubner [27].

\subsection{Maize/Corn}

In maize, common rust and northern corn leaf blight resistance can be obtained from Lr34, a durable wheat disease resistance gene [28]. Introgression of genes from two close wild relatives of maize, Tripascum and Zea mexicana, have enhanced yields in maize. A relevant review discussed two critical aspects of the pathosystem of Northern corn leaf blight (NCLB; the most devastating leaf pathogen affecting maize): the genetics of the fungus Setosphaeria turcica as well as the inheritance mechanisms of the host plant maize, along with successful breeding strategies to build resistance to NCLB [29]. Quantitative resistance to many pathogens have recently been reported to be conferred by a gene encoding maize caffeoyl-CoA O-methyltransferase [30]. Moreover, a novel quantitative trait locus (QTL) has been identified, characterized and mapped to a single gene containing a NAC-domain transcription factor (NAC7), which could be a target for improving functional stay-green and yield in maize and other crops [31].

\subsection{Sugarcane}

Nobilization of cane, referring to breeding theory of development and utilization of wild germplasm, is a well-established case of varietal improvement by harnessing the plant genetic resources. In case of sugarcane, genome characterization, mapping for specific traits, molecular variability of pathogens, selection for insect/disease resistance by virtue of markers, accurate identification of plant pathogens, transformation etc. have been aided by biotechnological modulations [32]. Sugarcane production technologies, integrated to foster cane and sugar productivity, would also serve to meet the goal of raising farmers' income [33].

\subsection{Others}

Some of the crops tested by the Department of Biotechnology (DBT) and the Indian Council of Agricultural Research (ICAR), are: 1) Bt cotton carrying the Cry1Ac gene, with resistance to American bollworm; 2) Bt rice with the Cry1Ac gene, resistant to yellow stem borer; 3) Bt brinjal (eggplant) carrying the Cry1 Ab gene, with resistance to fruit and shoot borer; 4) tomato carrying the $\mathrm{AmAl}$ gene from amaranth, with resistance to leaf curl virus; 5) protein-enriched potato; and 6) tomato and mustard with tolerance to salinity and drought. Since introduction of $\mathrm{Bt}$ technology, empirical evidences of improved cotton yield in India and a positive effect on long-term productivity at the national level have been reported [5]. Moreover, the formation of harmful substances such as aflatoxin in groundnuts, neurotoxins in khesari dal and cyanide in tapioca, besides several undesirable elements in sweet pea, chickpea and potato can be prevented by modern plant biotechnological underpinnings towards ensuring the quality and safety of the edible components.

As reviewed here, the crop-specific interventions proven to meet the heightening requirements of food/grain production and nutritional quality in Indian regions could contribute to further improve research in plant biotechnology or related disciplines of research in other parts of the country as well as the world. This relies on the predominance of tissue culture and micropropagation, exploitation of heterosis vigor, genetic enhancement of important crop plants, development of new hybrids and planting material with desirable traits in India; some useful traits have been noted practically in every cultivated crop, field or horticultural, through intergeneric or interspecific crossing. On the other hand, the effective global research strategies cited in this report could potentially be applied to add value to the booming agricultural sectors within India.

\section{Discussion}

Leveraging plant biotechnology is crucial in enhancing crop production to supply growing domestic needs and new export market demands. However, multiple legal and regulatory hurdles 
along with socio-economic and health concerns may limit transfer of transgenic plants from laboratory to crop-fields. Besides, biotechnologists as well as the public often apprehend the likelihood of development of super weeds, resistance genes in insects etc. Additionally, the seed terminator technology compels farmers to purchase seeds for each new cultivar. Optimizing fundamental plant developmental traits such as overall plant architecture, leaf structure and morphological features, vascular system and flowering time could play key roles in increasing biomass and crop yield [34].

Interestingly, non-controlled activation of protein translation and photosynthesis has been revealed by proteomic investigations in a rice $n p p 1$ mutant under conditions of elevated temperature and carbon dioxide [35]. In the $n p p 1$ mutants, increased expression of several 14-3-3 proteins was noted, indicating that the NPP1 gene disruption can alter protein phosphorylation status. Expression of Os14-3-3 gene has been studied in in indica rice cultivars which vary in tolerance to abiotic stress [36]. The 14-3-3 gene family members were analyzed in sorghum, foxtail millet, and maize, highlighting their gene structure, evolutionary and phylogenetic relationships, protein structure, and patterns of expression amid hormonal treatments and abiotic stresses; this study also suggested influence of 143-3 proteins in splicing processes [37]. The 14-33 acts as a stress response protein against heat, salinity and drought in Triticum aestivum (wheat) and related species, and mutational effects on its structure and function have been analyzed [38]. The 14-3-3 (YWHA or tyrosine 3monooxygenase/tryptophan 5-monooxygenase activation protein) are a family of homologous, acidic proteins expressed abundantly and ubiquitously in most eukaryotes, and exist as different species-specific isoforms, with seven in mammals [39-42]. They govern critical cellular events such as cell cycle, cell division, signalling and development in various animal species [4347]. These proteins are highly conserved and serve as stress-adaptive signalling agents [48]. Comparable to the above observations in plants, the 14-3-3 are known to interact with and control the expression, distribution and/roles of other cell cycle regulatory proteins in a phosphorylation-dependent manner (e.g. cell division cycle $25 \mathrm{~B}$ or $\mathrm{CDC} 25 \mathrm{~B}$ ) in various tissues and organs of several animal species [49-54].

Biotechnological approaches such as in vitro culture could be very useful for the maintenance of ex situ germplasm collections of asexually propagated crop species like banana, onion and garlic, low fertility polyploid species, and species which are not easy to be maintained either as seeds or in field gene-banks. For instance, potato, an important component of diet for many people in developing as well as developed countries, must be targeted for healthier human nutrition. The biological function of AmA1 is not known but it might act by inducing protein synthesis or mitogenic activity, similar to the result of over-expressing AmA1 or its turn-over products as signal molecules [20]. Genetic analyses as well as morphological studies used to distinguish among taxonomically different plants could assist better utilization of biotechnological manipulations and breeding in plants [55]. Given the present global economic crisis due to the Coronavirus Infectious Disease 2019 (COVID-19) pandemic, knowledge of plant biotechnology to address real-world issues such as intensifying food demand could also enhance awareness and interest in science and technology research among today's youth through innovative modes of currently online science education like mobile applications and virtual classrooms [56-58]. On the other hand, owing to this pandemic, stockpiling and panic-purchasing of foods have added to the agricultural needs across the world [59].

Implementation of the scientific techniques require trained human resources and an effective infrastructure. Furthermore, the biotechnological advances need to be complemented by appropriate legislation and regulatory bodies to not only raise food production but also ensure food safety and security [60]. As in the case of golden rice, thorough testing of transgenic plants is essential. Quality control laboratories may be established to prove that the transgenic products created do not 
pose any health-related, environmental, or other hazards whatsoever. Since new agricultural technologies are increasingly complex, knowledge intensive, expensive, and locationspecific, establishment of clear priorities could be recommended. Appropriate strategies must be designed and implemented towards generating and sustaining high-yield, disease-resistant crops for poverty reduction, food security, bioremediation, and environmental conservation.

\section{Conclusions}

This paper encapsulates notable plant biotechnological strategies reported by scientists, mainly during the last two decades, targeting relevant grain and seed crops of prominent agricultural as well as dietary importance to meet the increasing demand of food and nutrition for humans and domestic animals in India. Furthermore, key global research results regarding improvements in productivity and quality of major food-grains are reviewed to guide their potential application in the Indian context. Such information would be valuable to address the pressing worldwide requirement of better and more food production in times of contemporary crisis such as the recent COVID19 pandemic. The plethora of plant biotechnological interventions undertaken to foster crop health and production in the second most populated and a highly biodiverse country, India, could serve as a model for other developing nations striving to meet the growing global demand of food and nutrition. The scientific advances achieved during the recent past would form a foundation for development of novel technologies in plant genetic engineering, tissue culture and transgenics to foster agricultural productivity at present and in future.

\section{Declarations}

\subsection{Acknowledgements}

The author is grateful to Dr. Sarmistha Raychaudhuri, Department of Biophysics, Molecular Biology and Bioinformatics, Rajabazar Science College, University of Calcutta, India for thoughful guidance and advice.

\subsection{Competing Interests}

The author declares no conflict of interest including any financial, personal, or other relationships with other people or organizations that could inappropriately influence or be perceived to influence the present work.

\section{How to Cite this Article:}

S. De, "Strategies of Plant Biotechnology to Meet the Increasing Demand of Food and Nutrition in India", Int. Ann. Sci., vol. 10, no. 1, pp. 7-15, Sep. 2020.

\section{References}

[1] K.M.A. Gartland and J. S. Gartland, "Contributions of biotechnology to meeting future food and environmental security needs," The EuroBiotech Journal, vol. 2, no. 1, pp. 2-9, 2018. https://doi.org/10.2478/ebtj-2018-0002

[2] R. E. Evenson and D. Gollin, "Assessing the impact of the green revolution, 1960 to 2000," Science, vol. 300, no. 5620, pp. 758-62, May 22003. https://doi.org/10.1126/science. 1078710

[3] U. B. Zehr, "Status of Plant Biotechnology in India," in Plant Biotechnology 2002 and Beyond: Springer, 2003, pp. 599-603. https://doi.org/10.1007/978-94-017-26795_124

[4] P. Pingali, A. Aiyar, M. Abraham, and A. Rahman, "Diet Diversity and the Declining Importance of Staple Grains," in Transforming Food Systems for a Rising India: $\quad$ Springer, 2019, pp. 73-91. https://doi.org/10.1007/978-3-030-14409-8_4

[5] S. K. Srivastava and D. Kolady, "Agricultural biotechnology and crop productivity: macro-level evidences on contribution of Bt cotton in India," Current Science, vol. 110, pp. 311-319, 2016. 10.18520/cs/v110/i3/311-319

[6] C. N. Neeraja, L. R. Vemireddy, S. Malathi, and E. A. Siddiq, "Identification of alternate dwarfing gene sources to widely used Dee-Gee-Woo-Gen allele of sd1 gene by molecular and biochemical assays in rice (Oryza sativa L.)," Electronic Journal of Biotechnology, vol. 12, no. 3, pp. 7-8, 2009. https://doi.org/10.2225/vol12-issue3fulltext-11

[7] N. Behura, P. Sen, and M. K. Kar, "Introgression of yellow stem borer (Scirpophaga incertulus) resistance genes into cultivated rice (Oryza sp.) from wild species," Indian Journal of Agricultural Sciences, vol. 81, no. 4, pp. 359-362, 2011. http://epubs.icar.org.in/ejournal/index.php/IJAgS/article /view/5375

[8] X. Ye et al., "Engineering the provitamin A ( $\beta$-carotene) biosynthetic pathway into (carotenoid-free) rice endosperm," Science, vol. 287, no. 5451, pp. 303-305, 2000. https://doi.org/10.1126/science.287.5451.303

[9] K. Chidambara Murthy, "Production Of Beta-Carotene from Cultured Dunaliella Sp. and Evaluation Of Biological Activities," University of Mysore, 2005. http://ir.cftri.com/id/eprint/347

[10] J. A. Paine et al., "Improving the nutritional value of Golden Rice through increased pro-vitamin A content," Nature biotechnology, vol. 23, no. 4, p. 482, 2005. https://doi.org/10.1038/nbt1082 
[11] L. Nie et al., "Aerobic rice for water-saving agriculture. A review," Agronomy for Sustainable Development, vol. 32, no. 2, pp. 411-418, 2012. https://doi.org/10.1007/s13593-011-0055-8

[12] R. Oliva et al., "Broad-spectrum resistance to bacterial blight in rice using genome editing," Nat Biotechnol, Oct 28 2019. https://doi.org/10.1038/s41587-019-0267-z

[13] S. De, "Identification and Cloning of Putative Serine Protease Inhibitor (Serpin) Genes in Rice (Oryza sativa) and a Preliminary Approach to Generate RNAi using the Cloned Sequences," Biology Commons Article pp. 1-33, 2019.

https://nsuworks.nova.edu/cnso_bio_facarticles/978

[14] P. K. Mandal, S. Rai, M. Kaushik, S. K. Sinha, R. K. Gupta, and A. Mahendru, "Transcriptome data of cultivated tetraploid and hexaploid wheat variety during grain development," Data in brief, vol. 22, pp. 551-556, 2019. https://doi.org/10.1016/j.dib.2018.12.058

[15] P. D. Olivera, M. N. Rouse, and Y. Jin, "Identification of New Sources of Resistance to Wheat Stem Rust in Aegilops spp. in the Tertiary Genepool of Wheat," (in English), Frontiers in Plant Science, vol. 9, no. 1719, 2018. https://doi.org/10.3389/fpls.2018.01719

[16] V. Shamanin et al., "Primary hexaploid synthetics: Novel sources of wheat disease resistance," Crop Protection, vol. 121, pp. $7-10, \quad 2019$. https://doi.org/10.1016/j.cropro.2019.03.003

[17] S. Goel, K. Singh, and N. Singh, "Wheat Improvement in India: Present and Future," in Wheat Biotechnology: Springer, 2017, pp. 61-82. https://doi.org/10.1007/9781-4939-7337-8_4

[18] G. Grover, A. Sharma, H. S. Gill, P. Srivastava, and N. Bains, "Rht8 gene as an alternate dwarfing gene in elite Indian spring wheat cultivars," PloS One, vol. 13, no. 6, p. e0199330, 2018. https://doi.org/10.1371/journal.pone.0199330

[19] S. Grewal and S. Goel, "Current research status and future challenges to wheat production in India," Indian Journal of Biotechnology, vol. 14, pp. 445-454, 2015. https://pdfs.semanticscholar.org/d06b/023e250b8879c8 e8aaf9bd2d1efefa574258.pdf

[20] S. Chakraborty, N. Chakraborty, and A. Datta, "Increased nutritive value of transgenic potato by expressing a nonallergenic seed albumin gene from Amaranthus hypochondriacus," Proceedings of the National Academy of Sciences, vol. 97, no. 7, pp. 37243729, 2000. https://doi.org/10.1073/pnas.97.7.3724

[21] S.S.M. Sun and Q. Liu, "Transgenic approaches to improve the nutritional quality of plant proteins," In Vitro Cellular \& Developmental Biology - Plant, vol. 40, no. 2, p. 155, 2004. https://doi.org/10.1079/IVP2003517

[22] S. Chakraborty et al., "Next-generation protein-rich potato expressing the seed protein gene AmA1 is a result of proteome rebalancing in transgenic tuber," Proceedings of the National Academy of Sciences vol. 107, no. 41, pp. 17533-17538, 2010. https://doi.org/10.1073/pnas.1006265107

[23] J.G. Wallis, H. Wang, and D. J. Guerra, "Expression of a synthetic antifreeze protein in potato reduces electrolyte release at freezing temperatures," Plant Molecular Biology, vol. 35, no. 3, pp. 323-330, 1997. https://doi.org/10.1023/A:1005886210159

[24] D. S. Bagri, D. C. Upadhyay, S. K. Jain, and C. Upadhyay, "Biotechnological improvement of nutritional and therapeutic value of cultivated potato,"
Front Biosci (Landmark Ed), vol. 10, pp. 217-228, 2018. $10.2741 / \mathrm{s} 510$

[25] J. Chaudhary et al., "Mutation Breeding in Tomato: Advances, Applicability and Challenges," Plants (Basel), vol. 8, no. 5, May 142019. 10.3390/plants 8050128

[26] B. A. Shinde, B. B. Dholakia, K. Hussain, A. Aharoni, A. P. Giri, and A. C. Kamble, "WRKY1 acts as a key component improving resistance against Alternaria solani in wild tomato, Solanum arcanum Peralta," Plant Biotechnology Journal, vol. 16, no. 8, pp. 1502-1513, 2018. 10.1111/pbi.12892

[27] N. Chaithra, R. P. Gowda, and N. Guleria, "Transformation of Tomato with Cry2ax1 by Biolistic Gun Method for Fruit Borer Resistance," International Journal of Agriculture, Environment and Biotechnology, vol. 8, no. 4, p. 795, 2015. 10.5958/2230732X.2015.00088.1

[28] J. Sucher et al., "The durable wheat disease resistance gene Lr34 confers common rust and northern corn leaf blight resistance in maize," Plant Biotechnol J, vol. 15, no. 4, pp. 489-496, Apr 2017. https://doi.org/10.1111/pbi.12647

[29] A. L. Galiano-Carneiro and T. Miedaner, "Genetics of Resistance and Pathogenicity in the Maize/Setosphaeria turcica Pathosystem and Implications for Breeding," Front Plant Sci, vol. 8, p. 1490, 2017. https://doi.org/10.3389/fpls.2017.01490

[30] Q. Yang et al., "A gene encoding maize caffeoyl-CoA Omethyltransferase confers quantitative resistance to multiple pathogens," Nat Genet, vol. 49, no. 9, pp. 13641372, Sep 2017. https://doi.org/10.1038/ng.3919

[31] J. Zhang et al., "Identification and characterization of a novel stay-green QTL that increases yield in maize," Plant Biotechnol J, vol. 17, no. 12, pp. 2272-2285, Dec 2019. https://doi.org/10.1111/pbi.13139

[32] R. Sengar, K. Sengar, and S. Garg, "Biotechnological approaches for high sugarcane yield," Plant sciences feed, vol. 1, no. 7, pp. 101-111, 2011. https://www.academia.edu/4598861/BIOTECHNOLOG ICAL_APPROACHES_FOR_HIGH_SUGARCANE_ YIELD

[33] P. Singh et al., "Integration of sugarcane production technologies for enhanced cane and sugar productivity targeting to increase farmers' income: strategies and prospects," 3 Biotech, vol. 9, no. 2, p. 48, Feb 2019. https://doi.org/10.1007/s13205-019-1568-0

[34] J. Mathan, J. Bhattacharya, and A. Ranjan, "Enhancing crop yield by optimizing plant developmental features," Development, vol. 143, no. 18, pp. 3283-94, Sep 152016. https://doi.org/10.1242/dev.134072

[35] T. Inomata et al., "Proteomics Analysis Reveals NonControlled Activation of Photosynthesis and Protein Synthesis in a Rice npp1 Mutant under High Temperature and Elevated $\mathrm{CO}(2)$ Conditions," Int J Mol Sci, vol. 19, no. 9, Sep 7 2018. 10.3390/ijms19092655

[36] N. Yashvardhini, S. Bhattacharya, S. Chaudhuri, and D. N. Sengupta, "Molecular characterization of the 14-3-3 gene family in rice and its expression studies under abiotic stress," Planta, vol. 247, no. 1, pp. 229-253, Jan 2018. 10.1007/s00425-017-2779-4

[37] K. Kumar, M. Muthamilarasan, V. S. Bonthala, R. Roy, and M. Prasad, "Unraveling 14-3-3 proteins in C4 panicoids with emphasis on model plant Setaria italica reveals phosphorylation-dependent subcellular 
Santanu De, Int. Ann. Sci.; Vol. 10, Issue 1, pp: 7-15, 2021

localization of RS splicing factor," PLoS One, vol. 10, no. 4, p. e0123236, 2015. 10.1371/journal.pone.0123236

[38] S. Bhattacharya, A. Banerjee, P. P. Sah, C. Mal, and S. Ray, "Mutations and functional analysis of 14-3-3 stress response protein from Triticum aestivum: An evolutionary analysis through in silico structural biochemistry approach," Computational biology and chemistry, vol. 77, pp. 343-353, 2018. https://doi.org/10.1016/j.compbiolchem.2018.09.013

[39] S. De, "Protein 14-3-3 (YWHA) isoforms and their roles in regulating mouse oocyte maturation," 2014. http://rave.ohiolink.edu/etdc/view?acc_num=kent14018 03571

[40] S. De, J. Marcinkiewicz, and D. Kline, "Expression of 14-3-3 Protein Isoforms in Different Stages of Follicular Development in Adult Mouse Ovaries," Biology of Reproduction, vol. 85, no. Suppl_1, p. 639, 2011. https://doi.org/10.1093/biolreprod/85.s1.639

[41] S. De, J. L. Marcinkiewicz, S. Vijayaraghavan, and D. Kline, "Expression of 14-3-3 protein isoforms in mouse oocytes, eggs and ovarian follicular development," $B M C$ Res Notes, vol. 5, p. 57, Jan 23 2012. 10.1186/17560500-5-57

[42] S. De, B. F. Villarreal, S. Vijayaraghavan, and D. Kline, "Identification of 14-3-3 Protein Isoforms and their Differential Subcellular Distribution in Mouse Oocytes and Eggs," Mol Biol Cell \#381 vol. 22, 2011. https://doi.org/10.1091/mbc.e11-08-0667

[43] S. De, "The 14-3-3 (YWHA) Proteins in Signalling and Development of the Fruit Fly, Drosophila melanogaster," International Annals of Science, vol. 9, no. 1, pp. 80-85, 2020. https://doi.org/10.21467/ias.9.1.80-85

[44] S. De, S. Davis, D. Letwin, C. Mozena, and D. Kline, "Protein 14-3-3 eta (YWHAH) is essential for normal meiotic spindle assembly during in vitro maturation of mouse oocytes," Mol Biol Cell, \#1967 vol. 23, 2012. https://doi.org/10.1091/mbc.e12-10-0757

[45] S. De and D. Kline, "Erratum to: evidence for the requirement of 14-3-3eta (YWHAH) in meiotic spindle assembly during mouse oocyte maturation," $B M C$ developmental biology, vol. 14, no. 1, p. 20, 2014. 10.1186/1471-213X-14-20

[46] S. De and D. Kline, "Evidence for the requirement of 143-3eta (YWHAH) in meiotic spindle assembly during mouse oocyte maturation," BMC Developmental Biology, vol. 13, no. 1, p. 10, 2013/04/01 2013. 10.1186/1471-213X-13-10

[47] S. De and D. Kline, "The importance of 14-3-3 (YWHA) proteins in mammalian reproduction and fertility," Conference Presentation, 29th Annual Graduate Research Symposium, Kent State University 2014. http://works.bepress.com/santanu-de/14/

[48] K. L. Pennington, T. Y. Chan, M. P. Torres, and J. L. Andersen, "The dynamic and stress-adaptive signaling hub of 14-3-3: emerging mechanisms of regulation and context-dependent protein-protein interactions," Oncogene, vol. 37, no. 42, pp. 5587-5604, 2018. https://doi.org/10.1038/s41388-018-0348-3

[49] S. De and D. Kline, "Interactions of 14-3-3 proteins with CDC25B phosphatase in ovaries and oocytes of adult mice," Conference Presentation, 26th Annual Graduate Research Symposium, Kent State University 2011. http://works.bepress.com/santanu-de/9/

[50] S. De, A. Reese, and D. Kline, "Interactions of 14-3-3 (YWHA) protein isoforms with $\mathrm{CDC} 25 \mathrm{~B}$ phosphatase in mouse oocytes," Mol Biol Cell, \#1571 vol. 23, 2012. https://doi.org/10.1091/mbc.e12-10-0757

[51] S. De, A. Reese, and D. Kline, "Interactions of 14-3-3 protein isoforms with $\mathrm{CDC} 25 \mathrm{~B}$ phosphatase in mouse oocyte maturation," Conference Presentation, Duolink User Meeting 2011. http://works.bepress.com/santanu$\mathrm{de} / 12 /$

[52] S. De, A. Reese, and D. Kline, "Duolink in situ proximity ligation assays reveal interactions of 14-3-3 protein isoforms with CDC25B phosphatase in mouse oocyte maturation," Conference Presentation, 27th Annual Graduate Research Symposium, Kent State University 2012. http://works.bepress.com/santanu-de/15/

[53] A. C. Detwiler, S. De, and D. Kline, "Interactions of YWHA (14-3-3) protein isoforms with CDC25B phosphatase in regulating mouse oocyte maturation," Conference Presentation, 48th Annual Meeting of the Society for the Study of Reproduction 2015. http://works.bepress.com/santanu-de/8/

[54] A. A. Eisa et al., "YWHA (14-3-3) protein isoforms and their interactions with $\mathrm{CDC} 25 \mathrm{~B}$ phosphatase in mouse oogenesis and oocyte maturation," BMC Developmental Biology, vol. 19, no. 1, p. 20, 2019/10/22 2019. https://doi.org/10.1186/s12861-019-0200-1

[55] S. De and S. Bandyopadhyay, "Molecular Taxonomy: An Approach Based on Molecular Markers," Science and Culture, vol. 74, pp. 397-496, 2008. https://nsuworks.nova.edu/cnso_bio_facarticles/940

[56] S. De and V. Nethi, "The potential of socio-biologically relevant mobile apps to attract girls to STEM," Biology Faculty Proceedings, Presentations, Speeches, Lectures 2019. https://nsuworks.nova.edu/cnso_bio_facpres/334

[57] V. Nethi and S. De, "The Potential of Socio-biologically Relevant Mobile Applications to Attract Girls to STEM," FDLA Journal, vol. 4, no. 1, 2019, Art. no. 4. https://nsuworks.nova.edu/fdla-journal/vol4/iss1/4

[58] S. De and G. Cavanaugh, "Navigating Healthcare Science Student Learning and Engagement Through Implementation of a Virtual Classroom," Biology Faculty Proceedings, Presentations, Speeches, Lectures 2020, Art. 419. https://nsuworks.nova.edu/cnso_bio_facpres/419

[59] M. Nicola et al., "The Socio-Economic Implications of the Coronavirus and COVID-19 Pandemic: A Review," International Journal of Surgery, vol. 78, pp. 185-193, 2020. 10.1016/j.ijsu.2020.04.018

[60] S. De, "Food safety: Steps of rising concern," Everyman's Science, vol. XLV, no. 4, pp. 219-222, 2010. https://nsuworks.nova.edu/cnso_bio_facarticles/941

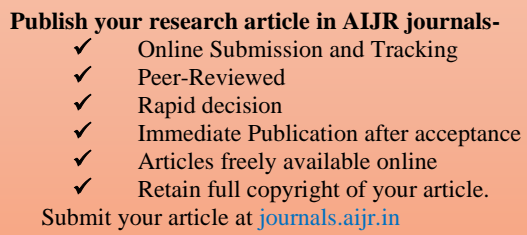

Publish your books with AIJR publisher-

$\checkmark \quad$ Publish with ISBN and DOI.

$\checkmark$ Publish Thesis/Dissertation as Monograph.

$\checkmark \quad$ Publish Book Monograph.

$\checkmark \quad$ Publish Edited Volume/ Book.

$\checkmark \quad$ Publish Conference Proceeding

$\checkmark \quad$ Retain full copyright of your books.

Submit your manuscript at books. aijr.org 